\title{
AN EXPLORATORY STUDY \\ OF A COMPARISON BETWEEN THE UK AND CZECH REPUBLIC OF THE FINANCIAL MODELS USED IN THE APPRAISAL OF ICT AND NON-ICT CAPITAL PROJECTS
}

Josef Hynek, Václav Janeček, Frank Lefley

\section{Introduction}

The importance of the financial appraisal of information technology projects is well stated in the IT, information management, and financial literature [17]. Too often, optimistic forecasted savings/benefits and underestimation of costs, together with the under-valuation of the capital cost of ICT projects have resulted in disastrous failures. ICT projects, like all other capital projects, must achieve a positive financial return. This paper examines the financial models used by both Czech Republic and UK organisations in the appraisal of ICT and non-ICT capital projects. Czech Republic and UK organisations were chosen, as the UK has been a free market economy for many years and the Czech Republic has been in a process of transformation from a state-owned to a free market economy over the past twenty years and is therefore, in some respects, an emerging market. In fact, the main purpose of the Czech government reforms introduced in Czechoslovakia since 1990 and the Czech Republic since 1993 has been the transformation of a centrally planned economy into a market economy. The questions that arise are, (i) Are the financial models used by the two countries the same? (ii) Is there a difference in the use of financial models between ICT and non-ICT projects? and (iii) Is there a difference in the level of importance placed on the various financial models used? An issue that has also been raised in the literature (see, for example, [16]) is that of the determination of the discount rate used in discounted cashflow (DCF) calculations. We also explore this issue in this paper.

\section{Literature Review}

While each financial model aims at assessing the acceptability of a project, each looks at acceptability from a different perspective, and consequently some models are not merely substitutes for others. Acceptability can be viewed from a 'value' perspective, in which case the net present value (NPV) is the most appropriate model to use. Both the internal rate of return (IRR) and accounting rate of return (ARR) are more a measure of performance and reward criteria, while the payback period (PB) aims to measure project liquidity. The perceived weaknesses of some of these models have resulted in the development of 'modified' models, such as the modified internal rate of return (MIRR), the profitability index $(\mathrm{PI})$, and the discounted payback period (DPB).

\subsection{Payback Period (PB)}

The PB model indicates how quickly the cost of an investment is recovered, but does not measure its profitability. It has long been recognised in the literature that this model is an inadequate measure of an investments worth as it is a cash concept, which is designed to answer the single question of how soon the original cash outlay will be recovered, it ignores the cashflows after the payback period [9], [24]. There is strong academic argument against the PB, for example, Pike [36, pp. 309] states, 'academic writers have almost unanimously condemned the use of the payback period as misleading and worthless in reaching investment decisions' Narayanan [34, pp. 309] states, 'the payback criterion continues to be 
widely used in industry, although there is little support for it among the academicians'; and Fisher and Nof [11, pp. 138] argue that the PB is a 'quick-and-dirty rule'. The two most serious disadvantages of the PB model of financial appraisal are (i) it does not take any regard of returns after the payback period and, (ii) it ignores the timing of the returns.

\subsection{The Discounted Payback Model (DPB)}

In order to overcome the timing of the returns issue of the conventional PB model, a discounted PB model was developed Rappaport [38]. In effect, the DPB is, but, a truncated version of the NPV - looking only at the discounted cashflows up to the payback period, and for this reason, it is not a measure of profitability but simply, like the standard PB model, a measure of liquidity [31], [25]. However, it does take into account a company's cost of capital.

\subsection{The Accounting Rate of Return (ARR)}

The ARR model attempts to equate the financial data of a capital project with the accrual concept of conventional accounting. It is an attempt to measure the profit and the capital cost on the same basis as that adopted in preparing the financial accounts of the organisation. The ARR expresses the average return on the investment as a percentage of that investment. The figure for investment may be either the initial capital cost of the project (initial capital model, or return on original investment) or, based on the assumption that the cost of the project will reduce to zero or a predetermined residual/ scrap value over the life of the project by way of depreciation, one half of the capital cost (average capital model, or return on average investment). The ARR does not take fully into account the fact that profits may vary year by year and, therefore, show an uneven pattern; it ignores the time value of the flow of funds, and is not suitable for comparing projects with different life spans. Kee and Bublitz [22] argue that an attraction of the ARR is its simplicity and articulation with accrual accounting measures, by which managers are frequently evaluated. Kelly and Tippett [23] argue that since the ARR is based on book values it is easy to compute and readily understandable by its users. Some academics report that the use of the ARR is in decline [27], while others show that it is a popular model in appraising IT projects [2].

\subsection{The Net Present Value (NPV)}

The literature repeatedly states that the NPV is the 'correct' investment appraisal model when looking to aim at maximising shareholder value, see for example Samuels et. al. [41] and Brealey \& Myers [6]. The NPV of a project is the sum of all the net discounted cashflows during the life of the project less the present value of the capital cost of the project. A positive NPV indicates that if the project is accepted then the organisation's wealth will increase by this NPV. If the NPV is negative then the result will be a reduction in an organisation's net worth, while a zero NPV will result in no change.

\subsection{The Profitability Index (PI)}

Some academics suggest that a possible weakness of the NPV is that it does not distinguish between projects of high and low value capital cost and does not therefore measure how profitable a project is in relation to the capital invested. This is of particular importance when a company is restricted in its capital expenditure through, for example, a liquidity shortage. The PI may, to some extent, solve this problem [39]. The PI [also called the benefit/cost ratio and the present value index $(\mathrm{PVI})]$ is a measure of relative profitability. It is calculated from the ratio between the net discounted benefits from a project and the capital investment (cost) required to achieve those benefits (hence the term benefit/cost ratio).

\subsection{The Internal Rate of Return (IRR)}

The IRR model (that is also referred to as the actuarial, the marginal efficiency of capital, and the yield model) uses the same net cashflows as the NPV model but expresses the result as a percentage yield. Provided this percentage yield is greater than the organisation's cost of finance/hurdle rate, then the project is said to be acceptable from a financial point of view. The IRR for a project is therefore the discount rate, which reduces the stream of net returns from with the project to a present value of zero. The IRR is more a measure of 'return' rather than an economic indicator of any increase in shareholder value, although even as a measure of return it has its critics. The IRR seems to have very little academic support. Hendricks [20, pp. 20] states: 'Using the IRR technique 
can result in incorrect rankings of mutually exclusive projects or multiple rates of return. The NPV technique avoids the multiple rate of return problem and gives correct rankings of mutually exclusive projects. NPV also provides unambiguous, optimal project selection when capital rationing exists. Thus the use of NPV, as opposed to IRR, will enable a firm to make capital budgeting decisions that maximize the present value of its expected cash flows.'

\subsection{The Modified Internal Rate of Return (MIRR)}

In order to overcome some of the deficiencies of the IRR, a modification to the standard IRR was introduced by Baldwin [1], see also Lin [29] who was possibly the first to use the term: modified internal rate of return - MIRR). Earlier work by Solomon [44] had, however, laid the foundation for Baldwin's 'modification' when Solomon set out to devise a way to solve the problem of multiple internal rate of returns a problem prone to the standard IRR when the cashflows from a project have more than one sign change: which is well recognised in the US from what is known as the Descartes' rule [29]. Such projects are said to be 'non-conventional', while, according to Beaves [4], a 'conventional' project is one where the sequence of cashflows has only a single sign change from negative to positive. Lefley [26] proves a link between the MIRR and the NPV.

The literature supports the view that advanced technology projects, such as ICT, should be appraised by the more sophisticated DCF financial models, see for example, Pike [37] or Fotr et al. [12].

The determination of the discount rate used in DCF calculations is a contentious issue [16]. The financial/economic theory literature argues that the discount rate should be equal to the prevailing rate in the capital market for the same level of risk, while the management accounting literature supports a 'cost of capital' approach. There are those that advocate a risk-free discount rate [1], [40], [35], [43], [14], [30] and further evidence suggests that the discount rate is being increased to take account of project specific risk [10]. Sundem [45, pp. 320] argues that the NPV model may be 'increased greatly' ... 'by assigning projects to two or three risk classes and using a different discount rate for evaluating projects in each risk class.' Levy and Sarnat [28] are of the opinion that the discount rate should be based on the weighted average cost of capital (WACC), although they argue that some changes may be needed to cover project specific risk. Mao [32] on the other hand, argues that it is usual to use a firm's 'marginal investment rate' as the discount rate for the NPV calculation. Mao also argues that the adoption of the 'cost of capital' approach in the determination of a discount rate may also include an allowance for corporate risk but usually excludes project specific risk. Let us not forget one original concept (at least from the accounting literature) of the NPV which is to calculate the net present value of future cashflows after taking into account the 'time value of money', and that discount rates were in fact based on interest rates [21]. Merrett and Sykes [33] argue that in arriving at a DCF discount rate, it is necessary to establish a meaningful 'time value of money'. The determination of the discount rate is perhaps the most difficult and the most controversial topic in the whole theory of finance [15]. There is therefore no consensus on how the discount rate should be determined, leaving managers' to use whatever approach they feel appropriate, with varying degrees of success. We therefore explore the following factors which the literature suggests influences the determination of the discount rate; opportunity cost of capital, project specific risk, inflation (time value of money), organisational risk, and taxation.

\section{Research Methodology}

This exploratory research is based on a factual and attitudinal survey conducted simultaneously in both the Czech Republic and the UK. The advantages and disadvantages of this type of survey are well known, but it still provides a useful data collection tool [13]. In general, the survey document was designed to make it clear that it was an academic study and not a commercial / marketing exercise. Statistical analysis of the factual survey in connection with project financial models used is based on the z-test. The attitudinal part of the survey was centred on a series of statements with responses based on a four-point Likert-type scale. A two-tailed t-test is used for analysing the differences in means between the UK and Czech Republic respondents' views. A standard crosscheck analysis was undertaken to verify the compatibility, reliability and validity of the data. The object of the survey was the identification 
of current practices in respect of the appraisal of both ICT and non-ICT projects and the opinions of senior executives on a number of important issues regarding such practices. This paper looks specifically at the financial models used to appraise ICT and non-ICT projects and what factors influence the determination of the discount rate in DCF calculations and is part of a much wider research study. More specifically, however, we tested the following hypotheses:

- $\mathrm{H} 1$ : There is no significant difference in the usage or importance of the PB models between the two countries.

- H2: There is no significant difference in the usage or importance of the PB models between ICT and non-ICT projects.

- H3: There is no significant difference in the usage or importance of the ARR models between the two countries.

- H4: There is no significant difference in the usage or importance of the ARR models between ICT and non-ICT projects.

- H5: There is no significant difference in the usage or importance of the NPV models between the two countries.

- H6: There is no significant difference in the usage or importance of the NPV models between ICT and non-ICT projects.

- H7: There is no significant difference in the usage or importance of the IRR/MIRR models between the two countries.

- H8: There is no significant difference in the usage or importance of the IRR/MIRR models between ICT and non-ICT projects.

- H9: There is no significant difference in the factors used to arrive at a DCF discount rate between the two countries.

- H10: There is no significant difference in the factors used to arrive at a DCF discount rate between ICT and non-ICT projects.

This is the only survey to address simultaneously the appraisal issues concerning ICT and non-ICT projects in both the Czech Republic and the UK.

Our research is empirical, in that it reports on what is actually done, and uses exploratory descriptive analysis to interpret the findings. It is also pragmatic in that it is concerned 'with what works' and ties up with the utilitarian arguments that what matters is what has 'utility to the individual'. We argue that our conclusions are pragmatic and have value in practical application.

\section{Research Results}

\subsection{Response and Sample Size}

The survey was simultaneously conducted in the Czech Republic and the UK and was addressed to large companies, measured by turnover, within each of the two countries. We look specifically at the Czech Republic - an emerging free-market economy and the UK a well-established free-market economy. The respondents were asked to answer certain questions in relation to the most recent ICT project that their organisation had evaluated with which they were familiar'. At the Czech Republic the respondents comprised of fortysix chief financial officers, twelve chief executive officers, thirteen IT/administration managers, and eight other managers from a range of areas of responsibility (two respondents did not state their area of responsibility). The respondents had worked an average of twelve years with their current employer.

The CZ survey resulted in a net sample of 625 of which eighty-one valid responses were received, giving a response rate of $13 \%$. The UK survey resulted in a net sample of 470 of which seventy-one valid responses were received, giving a net response rate of $15.1 \%$. These response rates were deemed acceptable when considering the current global economic recession and the strategic nature of the questionnaire. The responses are in line with, for example [7], who achieved a response rate of $16 \%$, and Sandahl and Sjögren [43] - group ' $\mathrm{B}$ ' $16.5 \%$. The number of usable responses were greater than that of Ward, et al. [47], who achieved a usable response of sixty, Ballantine and Stray [3], who achieved a usable response of fifty-six in the second stage of their research, Harris, et al. [19] who achieved a usable response from sixty-five companies and Berry [5], who received a usable response of thirtynine.

We accept that non-response bias, as with all postal surveys, may present a problem if one is of the opinion, for example, that the nonrespondents are those that do not appraise their capital projects in any robust manner and have deliberately chosen not to reveal such matters by not completing the questionnaire. We do not necessarily support this view, especially as the organisation classifications of the respondents' mirrors the target samples, but we do accept that the research results may have some limitations in terms of drawing general conclusions. 


\begin{tabular}{|c|c|c|c|c|c|c|c|}
\hline \multirow{2}{*}{ Model: } & \multicolumn{2}{|c|}{$(n=74)$} & \multicolumn{4}{|c|}{ Ranked } & \multirow{2}{*}{ Ranking } \\
\hline & (a) & (b) & 1st & 2nd & 3rd & 4th & \\
\hline Payback discounted + conventional ${ }^{*}$ & 66 & 63 & 37 & 20 & 6 & 0 & 2.7500 \\
\hline $\begin{array}{l}\text { Payback (conventional / non-discounted } \\
\text { figures) (PB) }\end{array}$ & 48 & 46 & 27 & 14 & 5 & 0 & 2.1622 \\
\hline Net Present Value (NPV) & 29 & 27 & 15 & 6 & 5 & 1 & 1.2027 \\
\hline $\begin{array}{l}\text { Return on investment / Accounting rate of } \\
\text { return (ROI/ARR) }\end{array}$ & 24 & 22 & 13 & 4 & 4 & 1 & 0.9865 \\
\hline $\begin{array}{l}\text { Discounted Payback (using discounted } \\
\text { figures) (DPB) }\end{array}$ & 18 & 17 & 10 & 6 & 1 & 0 & 0.8108 \\
\hline $\begin{array}{l}\text { Internal Rate of Return + Modified Internal } \\
\text { Rate of Return* }\end{array}$ & 14 & 12 & 4 & 4 & 2 & 2 & 0.4595 \\
\hline Internal Rate of Return (IRR) & 14 & 12 & 4 & 4 & 2 & 2 & 0.4595 \\
\hline Other & 5 & 4 & 3 & 0 & 1 & 0 & 0.1892 \\
\hline Profitability Index (PI) & 5 & 4 & 1 & 1 & 2 & 0 & 0.1486 \\
\hline Modified Internal Rate of Return (MIRR) & 0 & 0 & 0 & 0 & 0 & 0 & 0 \\
\hline
\end{tabular}

Note: Two respondents' did not give a ranking to the models they used. (n): (a) total number, (b) total number ranked. Seven respondents' used both the PB and DPB. Only one respondent used five financial models; this respondent's 5th rank (ROI/ARR) has been included in rank 4 for calculations purposes. 7 respondents did not answer the question. 42 (56.8\% of the 74 respondents who answered this question) used one or more of the DCF models.

*The description refers to a combination of related models.

\subsection{Financial Appraisal Models Used}

\section{H1: There is no significant difference in the usage or importance of the PB models between the two countries. \\ H2: There is no significant difference in the usage or importance of the PB models between ICT and non-ICT projects.}

The payback (including discounted payback) model of investment appraisal continues to be the most favoured by practitioner (see, tables 1 and 2), with fifty-nine (i.e. 66 less seven respondents who used both the PB and DPB) $[79.7 \%$, importance ranking 2.7500] of Czech Republic organisations and sixty-two [87.3\%, importance ranking 2.6216] of UK organisations, using this method with respect to ICT projects. With respect to non-ICT projects (see, tables 3 and 4) the figures are, respectively, fifty-nine (i.e. 65 less six respondents who used both the PB and DPB) [CR $-89.0 \%$, importance ranking 2.7531] and sixty [UK $-90.9 \%$, importance ranking 2.4730 ]. There is no significant difference at the $p<0.01$ level in usage or importance between the two countries.

It is interesting to note that the CZ makes less use of the DPB model than the UK. With respect to ICT projects the number of CZ organisation that use the DPB is eighteen (importance ranking 0.8108 ), while the UK organisations numbered thirty-seven (importance ranking 1.5270). For non-ICT projects the numbers were, respectively, CZ nineteen (importance ranking 0.8649) and UK thirty-six (importance ranking 1.4054). The figures show no significant difference between the use of DPB between the two types of projects, but there is a significant difference at the $p<0.01$ level between the two countries usage with respect to both ICT (The $z$-score is -3.4474 . The $p$-value is 0.00056 ) and non-ICT projects (The $z$-score is -3.4335 . The $\mathrm{p}$-value is 0.0006).

The CZ, however, makes greater use of the conventional PB (non-discounted) model than the UK. With respect to ICT projects the number of $\mathrm{CZ}$ organisation that use the DPB is forty-eight (importance ranking 2.1622), 


\begin{tabular}{l|c|c|c|c|c|c}
\multirow{2}{*}{ Model (in order of perceived importance) } & \multirow{2}{*}{$(\mathbf{n}=\mathbf{7 1})$} & \multicolumn{3}{|c|}{ Ranked } & \multirow{2}{*}{ Ranking } \\
\cline { 4 - 6 } & & $\mathbf{1 s t}$ & $\mathbf{2 n d}$ & $\mathbf{3 r d}$ & 4th & \\
\hline $\begin{array}{l}\text { Payback discounted/conventional } \\
\text { (no company used both)* }\end{array}$ & 62 & 25 & 21 & 15 & 1 & 2.6216 \\
\hline $\begin{array}{l}\text { Internal Rate of Return/ Modified Internal } \\
\text { Rate of Return* }\end{array}$ & 47 & 22 & 14 & 9 & 2 & 2.0270 \\
\hline Net Present Value (NPV) & 50 & 18 & 17 & 11 & 4 & 2.0135 \\
\hline Internal Rate of Return (IRR) & 40 & 20 & 12 & 7 & 1 & 1.7703 \\
\hline $\begin{array}{l}\text { Discounted Payback (using discounted } \\
\text { figures) (DPB) }\end{array}$ & 37 & 14 & 12 & 10 & 1 & 1.5270 \\
\hline $\begin{array}{l}\text { Payback (conventional/non-discounted } \\
\text { figures) (PB) }\end{array}$ & 25 & 11 & 9 & 5 & 0 & 1.0946 \\
\hline $\begin{array}{l}\text { Return on investment / Accounting rate } \\
\text { of return (ROI/ARR) }\end{array}$ & 26 & 6 & 14 & 4 & 2 & 1.0270 \\
\hline Profitability Index (PI) & 12 & 0 & 1 & 6 & 5 & 0.2703 \\
\hline Modified Internal Rate of Return (MIRR) & 7 & 2 & 2 & 2 & 1 & 0.2568 \\
\hline
\end{tabular}

*The description refers to a combination of related models. All respondents (71) reported on and ranked financial models in respect of ICT projects.

while the UK organisations numbered twentyfive (importance ranking 1.0946). For non-ICT projects the numbers were, respectively, CZ forty-six (importance ranking 2.1486) and UK twenty-four (importance ranking 1.0676). The figures show no significant difference between the use of PB for each of the two types of projects, but there is a significant difference at the $p<0.01$ level between the two countries usage with respect to both ICT (The z-score is 3.5701. The p-value is 0.00036) and non-ICT projects (The z-score is 3.1381 . The p-value is 0.00168). There is also a difference in the importance ranking between the two countries with respect to ICT and non-ICT projects, with the $\mathrm{CZ}$ placing a greater level of importance on the PB than the UK.

H3: There is no significant difference in the usage or importance of the ARR models between the two countries.

$\mathrm{H} 4$ : There is no significant difference in the usage or importance of the ARR models between ICT and non-ICT projects.

With respect to ICT projects, twenty-four (ranking 0.9865) CZ organisations use the ROI/ARR and twenty-six (ranking 1.0270)
UK organisations. Eighteen (ranking 0.7297) CZ and twenty-two (ranking 0.8514) UK organisations use the ROI/ARR, with respect to non-ICT projects. There is no significant difference at the $p<0.01$ level in these figures.

H5: There is no significant difference in the usage or importance of the NPV models between the two countries.

$\mathrm{H6}$ : There is no significant difference in the usage or importance of the NPV models between ICT and non-ICT projects.

The NPV was used by twenty-nine (ranked by twenty-seven; ranking 1.2027) CZ organisations with respect of ICT projects and twenty-five (ranked by twenty-three; ranking 1.0135) in respect of non-ICT projects. With regard to UK organisations, the figures are fifty (ranking 2.0135) for ICT projects and forty-five (ranking 1.8514) with respect to nonICT projects. The figures show no significant difference between the use of NPV between the two types of projects, but there is a significant difference at the $p<0.01$ level between the two countries (UK-CZ ICT projects; the z-score is -3.7754 and the $p$-value is 0.00016 , UK-CZ non-ICT projects; the z-score is -3.9959 and 
Tab. 3: CZ Financial models used in appraising the most recent non-ICT project

\begin{tabular}{|c|c|c|c|c|c|c|c|}
\hline \multirow{2}{*}{ Model: (in order of perceived importance) } & \multicolumn{2}{|c|}{$(n=73)$} & \multicolumn{4}{|c|}{ Ranked } & \multirow{2}{*}{ Ranking } \\
\hline & (a) & (b) & 1st & 2nd & 3rd & 4th & \\
\hline Payback discounted + conventional $^{*}$ & 65 & 62 & 41 & 17 & 4 & 0 & 2.7531 \\
\hline $\begin{array}{l}\text { Payback (conventional / non-discounted } \\
\text { figures) (PB) }\end{array}$ & 46 & 44 & 30 & 11 & 3 & 0 & 2.1486 \\
\hline Net Present Value (NPV) & 25 & 23 & 12 & 6 & 4 & 1 & 1.0135 \\
\hline $\begin{array}{l}\text { Discounted Payback (using discounted } \\
\text { figures) (DPB) }\end{array}$ & 19 & 18 & 11 & 6 & 1 & 0 & 0.8649 \\
\hline $\begin{array}{l}\text { Internal Rate of Return + Modified Internal } \\
\text { Rate of Return* }\end{array}$ & 20 & 18 & 6 & 8 & 2 & 2 & 0.7297 \\
\hline $\begin{array}{l}\text { Return on investment / Accounting rate } \\
\text { of return (ROI/ARR) }\end{array}$ & 18 & 16 & 10 & 3 & 2 & 1 & 0.7297 \\
\hline Internal Rate of Return (IRR) & 17 & 16 & 4 & 8 & 2 & 2 & 0.6216 \\
\hline Other & 5 & 4 & 4 & 0 & 0 & 0 & 0.2162 \\
\hline Profitability Index (PI) & 5 & 4 & 2 & 0 & 2 & 0 & 0.1622 \\
\hline Modified Internal Rate of Return (MIRR) & 3 & 2 & 2 & 0 & 0 & 0 & 0.1081 \\
\hline
\end{tabular}

Note: Two respondents did not give a ranking to the models they used. (n): (a) total number, (b) total number ranked. Six respondents' used both the PB and DPB. Only one respondent used five financial models; this respondent's 5th rank (ROI/ARR) has been included in rank 4 for calculations purposes. 42 (57.5\% of the 73 respondents who answered this question) used one or more of the DCF models.

*The description refers to a combination of related models.

Source: own

the $p$-value is 0), with the UK making greater use (and higher ranking) of the NPV than the CZ. However, the CZ organisations prefer the NPV to the IRR with such difference shown to be significant at the $p<0.01$ level with respect to ICT projects (the z-score is 2.7158 and the p-value is 0.00652), but not shown to be significant with respect to non-ICT projects (the $z$-score is 1.4626 and the $p$-value is 0.1443 , the result is not significant at $p<0.10$ ).

The profitability index $(\mathrm{PI})$, which may to some extent solve the perceived problem of the NPV regarding the profitability of a project in relation to capital invested [39], was used by five (ranked by four; ranking 0.1486 ) CZ organisations with respect of ICT projects and five (ranked by four; ranking 0.1622 ) in respect of non-ICT projects. With regard to UK organisations, the figures are twelve (ranking 0.2703 ) for ICT projects and eleven (ranking 0.2162 ) with respect to non-ICT projects. There is no significant difference at the $p<0.01$ level in these figures.
H7: There is no significant difference in the usage or importance of the IRR/MIRR models between the two countries.

H8: There is no significant difference in the usage or importance of the IRR/MIRR models between ICT and non-ICT projects.

The IRR/MIRR was used by fourteen (ranked by twelve; ranking 0.4595$) \mathrm{CZ}$ organisations with respect of ICT projects and twenty (ranked by eighteen; ranking 0.7297 ) in respect of nonICT projects. With regard to UK organisations, the figures are forty-seven (ranking 2.0270) for ICT projects and forty-four (ranking 1.9459) with respect to non-ICT projects. The figures show no significant difference between the use of IRR/MIRR between the two types of projects, but there is a significant difference at the $p<0.01$ level between the two countries (UK-CZ ICT projects; the Z-score is -4.6591 and the $p$-value is 0 , UK-CZ non-ICT projects; the $z$-score is -4.6385 and the p-value is 0$)$, with the UK making greater use (and higher ranking) of the IRR/MIRR than the CZ. It is interesting to note that with respect to the MIRR, no CZ 
Tab. 4: UK Financial models used in appraising the most recent non-ICT project

\begin{tabular}{|c|c|c|c|c|c|c|}
\hline \multirow{2}{*}{ Model (in order of perceived importance) } & \multirow{2}{*}{$(n=66)$} & \multicolumn{4}{|c|}{ Ranked } & \multirow{2}{*}{ Ranking } \\
\hline & & 1st & 2nd & 3rd & 4th & \\
\hline $\begin{array}{l}\text { Payback discounted/conventional } \\
\text { (no company used both)* }\end{array}$ & 60 & 22 & 21 & 15 & 2 & 2.4730 \\
\hline $\begin{array}{l}\text { Internal Rate of Return/ Modified Internal Rate } \\
\text { of Return* }\end{array}$ & 44 & 23 & 11 & 9 & 1 & 1.9459 \\
\hline Net Present Value & 45 & 17 & 15 & 11 & 2 & 1.8514 \\
\hline Internal Rate of Return & 38 & 21 & 10 & 7 & 0 & 1.7297 \\
\hline $\begin{array}{l}\text { Discounted Payback (using discounted } \\
\text { figures) }\end{array}$ & 36 & 11 & 12 & 11 & 2 & 1.4054 \\
\hline $\begin{array}{l}\text { Payback (conventional/non-discounted } \\
\text { figures) }\end{array}$ & 24 & 11 & 9 & 4 & 0 & 1.0676 \\
\hline $\begin{array}{l}\text { Return on investment / Accounting rate } \\
\text { of return }\end{array}$ & 22 & 4 & 13 & 3 & 2 & 0.8514 \\
\hline Profitability Index & 11 & 0 & 0 & 5 & 6 & 0.2162 \\
\hline Modified Internal Rate of Return & 6 & 2 & 1 & 2 & 1 & 0.2162 \\
\hline $\begin{array}{l}\text { Other: If NPV is negative then take other } \\
\text { factors into account }\end{array}$ & 1 & 0 & 1 & 0 & 0 & 0.0405 \\
\hline
\end{tabular}

Note: Sixty-six respondents reported on and ranked financial models in respect of non-ICT projects. Two organisations did not use any financial model but relied solely on corporate management judgement (strategic assessment).

*The description refers to a combination of related models.

Source: own

\section{Tab. 5: Factors taken into account when determining the DCF discount rate}

\begin{tabular}{l|c|c|c|c}
\multirow{2}{*}{} & \multicolumn{2}{|c|}{ UK } & \multicolumn{2}{c}{ Czech Republic } \\
\cline { 2 - 5 } & ICT & non-ICT & ICT & Non-ICT \\
\hline Factor & $(\mathrm{n}=60)$ & $(\mathrm{n}=56)$ & $(\mathrm{n}=42)$ & $(\mathrm{n}=42)$ \\
\hline Opportunity cost of capital & 48 & 41 & 14 & 14 \\
\hline Project-specific risk & 21 & 18 & 15 & 17 \\
\hline Taxation & 18 & 16 & 8 & 11 \\
\hline Inflation & 16 & 16 & 26 & 29 \\
\hline Organisational risk & 9 & 11 & 11 & 11 \\
\hline Other & 2 & 1 & 6 & 4 \\
\hline
\end{tabular}

Note: UK - ICT: Sixty (84.5\%) organisation used one or more of the DCF models. Non-ICT: Fifty-six $(78.8 \%)$ organisations used one or more of the DCF models. CZ - ICT: Forty-two (56.8\% of the 74 respondents who answered the question on financial models) used one or more of the DCF models. Non-ICT: Forty-two $(57.5 \%$ of the 73 respondents who answered the question on financial models) used one or more of the DCF models. 
organisation used this modified model to assess ICT projects, but three CZ organisations did use this model for non-ICT projects.

Five CZ organisations quoted 'other' financial appraisal approaches, including, nondiscounted cashflows, size of cost savings, on time and on budget (post evaluation), and simplification of information flow.

\subsection{Factors Influencing the Determination of DCF Discount Rates}

\begin{abstract}
H9: There is no significant difference in the factors used to arrive at a DCF discount rate between the two countries.

$\mathrm{H10}$ : There is no significant difference in the factors used to arrive at a DCF discount rate between ICT and non-ICT projects.
\end{abstract}

As the literature identifies conflicting views on how the discount rate used in the DCF models should be determined, we set out to investigate what factors in practice influenced this rate. We analysed the various factors between ICT and non-ICT projects and between $\mathrm{CZ}$ and UK organisations (see tab. 5). With respect to the UK, and for ICT projects, sixty $(84.5 \%)$ organisations used one or more of the DCF models. With respect to non-ICT projects, the figure was fifty-six $(78.8 \%)$. With respect to the $\mathrm{CZ}$, and for ICT projects, forty-two (56.8\% of the seventy-four respondents who answered the question on financial models) used one or more of the DCF models. With respect to nonICT projects, the figure was forty-two $(57.5 \%$ of the seventy-three respondents who answered the question on financial models). With respect to the UK, the most favoured factor was the 'opportunity cost of capital' used by forty-eight $(80 \%)$ organisations with respect to ICT projects [forty-one $(73.2 \%)$ for non-ICT projects]. This was followed by 'project specific risk' which was used by twenty-one (35\%) organisations with respect to ICT projects [eighteen (32.1\%) for non-ICT projects]. The most favoured factor among $\mathrm{CZ}$ organisations was 'inflation', i.e., time value of money, used by twenty-six (61.9\%) organisations with respect to ICT projects [twenty-nine $(69 \%)$ for non-ICT projects]. There is, however, a danger that the discount rate could include an allowance for inflation whilst it is ignored in the forecasted cashflows [8].This was followed by 'project specific risk', which was used by fifteen (35.7\%) organisations with respect to ICT projects [seventeen $(40.5 \%)$ for non-ICT projects.

While there was no significant difference in the factors, in either country, between ICT and non-ICT projects, there was a significant difference in some aspects between the two countries. The greater use of 'opportunity cost of capital' by UK organisation was significantly different from the $C Z$ at $p<0.01$ (with respect to ICT projects the $z$-score is 4.751 . The $p$-value is 0 ; with respect to non-ICT projects, the z-score is 3.9371 . The $p$-value is 0 ). The greater use of 'inflation' by $\mathrm{CZ}$ organisation was significantly different from the UK at $p<0.01$ (with respect to ICT projects the z-score is -3.5589 . The $p$-value is 0.0004 ; with respect to non-ICT projects, the $z$-score is -3.9791 . The $p$-value is 0$)$. With respect to the factor 'project specific risk', there was no significant difference between the two countries at $p<0.10$ (with respect to ICT projects the $z$-score is -0.0743 . The $p$-value is 0.9442 ; with respect to non-ICT projects, the $z$-score is -0.852 . The $p$-value is 0.3953$)$. With respect to the factor 'taxation, there was no significant difference between the two countries at $p<0.10$ (with respect to ICT projects the $z$-score is 1.2492 . The $p$-value is 0.2113 ; with respect to non-ICT projects, the z-score is 0.2611 . The $p$-value is 0.7949 ).

\subsection{Respondents' Opinions}

Although the PB model is the most popular model in both the CZ and UK in respect of ICT and non-ICT project appraisals, it is interesting to note that there is a general opinion that this approach encourages a short-term view. A large number (see tab. 6) of both UK (mean 2.7606) and CZ (mean 2.6538) respondents agreed with the statement, 'The Payback model of financial appraisal encourages a short term view', with no significant difference $(\mathrm{t}=0.9525)$ between the opinions of the respondents between the two countries. However, there is a significant difference at the $\alpha=1 \%$ level ( $t=-5.0587$ ) between the opinions of the UK and $\mathrm{CZ}$ in respect of the following statement, 'The Payback model of financial appraisal is unsuitable for evaluating investments in ICT'. It appears that the $\mathrm{CZ}$, although heavily relying on the PB model, are of the opinion that it is unsuitable for evaluating ICT projects!

The difficulty experienced in cashflow determination with respect to ICT projects 
Tab. 6: Statistical analysis of responses to opinion statements

\begin{tabular}{|c|c|c|c|c|c|c|c|c|c|c|c|}
\hline \multirow{2}{*}{ Statement: } & \multicolumn{5}{|c|}{ UK } & \multicolumn{5}{|c|}{$\mathrm{CZ}$} & \multirow{2}{*}{ t-values } \\
\hline & a & b & c & d & mean & a & b & c & d & mean & \\
\hline $\begin{array}{l}\text { (i) The Payback model of financial appraisal } \\
\text { encourages a short term view }\end{array}$ & 10 & 34 & 27 & 0 & 2.7606 & 6 & 42 & 27 & 3 & 2.6538 & 0.9525 \\
\hline $\begin{array}{l}\text { (ii) The Payback model of financial appraisal is } \\
\text { unsuitable for evaluating investments in ICT. }\end{array}$ & 3 & 8 & 40 & 20 & 1.9155 & 11 & 26 & 38 & 4 & 2.5570 & $-5.0587^{*}$ \\
\hline $\begin{array}{l}\text { (iii) Projected cashflows from ICT projects are } \\
\text { more difficult to determine than those in respect } \\
\text { of investments in non-ICT capital projects. }\end{array}$ & 11 & 38 & 21 & 1 & 2.8310 & 14 & 44 & 15 & 4 & 2.8831 & -0.4337 \\
\hline $\begin{array}{l}\text { (iv) Many of the appraisal models available to } \\
\text { assess capital projects are too theoretical and } \\
\text { difficult to apply in the real world. }\end{array}$ & 8 & 47 & 16 & 0 & 2.8873 & 16 & 42 & 17 & 1 & 2.9605 & -0.6896 \\
\hline $\begin{array}{l}\text { (v) A single practical (pragmatic) appraisal model } \\
\text { that links together, finance, project-specific risk, } \\
\text { and strategic issues would make the evaluation of } \\
\text { ICT projects more meaningful. }\end{array}$ & 17 & 53 & 1 & 0 & 3.2254 & 7 & 42 & 19 & 5 & 2.6986 & $5.1356^{*}$ \\
\hline
\end{tabular}

Note: Level of agreement with each statement: a = 'strongly agree'; $b$ = 'agree'; c = 'disagree'; and d = 'strongly disagree'. ${ }^{\star} A$ significant difference at the $\alpha=1 \%$ level (reject $\mathrm{H} 0$, that means are equal).

Source: own

is emphasised by the agreement to the following statement, 'Projected cashflows from ICT projects are more difficult to determine that those in respect of investments in nonICT capital projects'. There is no significant difference $(t=-0.4337)$ between the opinions of the UK (mean 2.8310) and CZ (mean 2.8831) respondents. This is also shown to be the case with respect to the following statement, 'Many of the appraisal models available to assess capital projects are too theoretical and difficult to apply in the real world'. Again, there is no significant difference $(\mathrm{t}=-0.6896)$ between the opinions of the UK (mean 2.8873) and CZ (mean 2.9605) respondents. The support for this statement may explain why there is such a high usage of the less-sophisticated PB model, even though the respondents believe it is unsuitable for appraising ICT projects.

The suggestion that a more pragmatic multi-aspect appraisal model may be more appropriate than the existing models is seen to have greater support among UK than CZ respondents. There is a significant difference at the $\alpha=1 \%$ level $(t=5.1356)$ between the opinions of the UK (mean 3.2254) and CZ (mean 2.6986) respondents to the following statement, 'A single practical (pragmatic) appraisal model that links together, finance, project-specific risk, and strategic issues would make the evaluation of ICT projects more meaningful'.

\section{Conclusion}

One of the important findings of this research is that any differences in the usage or level of importance of the financial appraisal models relate to the two countries rather than between ICT or non-ICT projects.

While there is no difference between the usage of the combined PB and DPB, our findings show that the $C Z$ favours the conventional payback approach, while the UK favours the discounted payback approach. The high usage and importance of the payback model may indicate that the current volatile economic environment, with its high level of uncertainty, together with the reward structure of many companies, encourages a short-term business culture [18]. Another explanation may be that the payback model serves as a first approximate assessment of a projects worth and that more sophisticated models, such as NPV and IRR, are applied if the PB looks promising. This consideration needs further critical analysis.

An interesting observation is that, while 
both the CZ and UK make extensive use of the payback model, they fully defend the view that this model influences a short-term mentality. The CZ, more so than the UK, also support the view that the payback is unsuitable for appraising ICT projects, yet they still use it to appraise such projects. This may suggest that the payback is not used as the main selection criteria, all be it an 'important' consideration, or that 'short-term' influences are very important to the appraisal team.

The CZ makes less use (and indicates lower rankings) of the DCF models than the UK, but the CZ does prefer the NPV to the IRR. Such difference was shown to be significant with respect to ICT projects. The greater preference for the NPV among CZ companies may reflect the 'rediscovery' by financial managers of the conventional DCF models and the 'persuasion' by academics of the correct approaches, such as NPV, through the Czech translation of such well-known western text books such as Brealey and Myers [6] during the Czech economy transformation after 1989.

The notion postulated in the literature that sophisticated projects, such as ICT, would be appraised using sophisticated models is not supported by this research. We support earlier literature over the concern of the limited use of DCF models in the appraisal of information technology projects and that more research is needed to ascertain why such models lack the importance they deserve. Is it that 'short-termism' is so embedded in present day business culture that DCF models will only play a supportive role to the less sophisticated payback model?

From our research findings, we support the view that the current financial models are appropriate to appraise both ICT and nonICT projects and that the problems regarding the financial appraisal of ICT projects lies in the determination of the cashflows from such projects. It is in this area that future research should be directed.

As part of our research study, we set out to investigate what factors in practice influenced the determination of the discount rate used in DCF calculations. From our literature review, we were able to identify a number of important factors, which practitioners may take into account when determining their own organisation's discount rate. While there was no significant difference in the factors, in either country, between ICT and non-ICT projects, there was a significant difference in some aspects between the two countries. With respect to the UK, the 'opportunity cost of capital' was shown to be the most common factor used, while with respect to the CZ, the most common factor was 'inflation'. 'Project specific risk', was shown to be the second most influencing factor with respect to both countries. It appears that the $\mathrm{CZ}$, being influence by inflationary factors, are adhering to the accounting text-book concept of the 'time value of money', while the UK are taking a more economic perspective. The UK, by using an opportunity cost of capital approach, may in fact be making it harder to achieve a positive NPV, and projects that are 'profitable' may be rejected. We would argue that any project that achieves a positive return above its 'true' cost of capital will enhance shareholder value. It may be that the $\mathrm{CZ}$ are adopting an approach, which is nearer to the true cost of capital than the UK. There is a serious need for clarification and simplification in the determination of the discount rate, especially if management, who are now considering investments in ICT, are to be convinced of the merits of DCF investment appraisal methods and are not left to rely on their own subjective judgement. It is equally essential that over exaggerated discount rates are not allowed to enter into the financial appraisal equation.

Future research should also look at testing the following hypotheses:

- $\mathrm{H} 1$ : Organisations in emerging markets are more likely to use the NPV financial model than the IRR to appraise ICT projects.

- H2: Organisations in emerging markets are more likely to base their DCF discount rates on the time value of money.

This exploratory study will aid both practitioners and academics in a greater understanding of the financial appraisal of both ICT and non-ICT capital projects and the appraisal differences between $\mathrm{CZ}$ and UK organisations. Our future research suggestions should help to focus academics in a constructive and positive way.

\section{References}

[1] BALDWIN, R.H. How to assess investment proposals. Harvard Business Review. 1959, Vol. 37, Iss. 3, pp. 98-104. ISSN 0017-8012.

[2] BALLANTINE, J., STRAY, S. Financial appraisal and the IS/IT investment decision 
making process. Journal of Information Technology. 1998, Vol. 13, Iss.1, pp. 3-14. ISSN 0268-3962. DOI:10.1080/026839698344927.

[3] BALLANTINE, J., STRAY, S. Information systems and other capital investments: evaluation practices compared. Logistics Information Management. 1999, Vol. 12, Iss. 1-2, pp. 78-93. ISSN 0957-6053. DOI: http:// dx.doi.org/10.1108/09576059910256286.

[4] BEAVES, R.G. Net present value and rate of return: implicit and explicit reinvestment assumptions. Engineering Economist. 1988, Vol. 33, Iss. 4, pp. 275-302. ISSN 0013-791X.

[5] BERRY, J. Canadian public relations students' interest in government communication - An exploratory study. Management Research Review. 2013, Vol. 36, Iss. 5, pp. 528-544. ISSN 2040-8269. DOI:http://dx.doi. org/10.1108/01409171311327262.

[6] BREALEY, R.A., MYERS, S.C. Teorie a praxe firemních financí. Praha: Victoria Publishing, 1992. ISBN 80-85605-24-4.

[7] COTTON, W.D.J., SCHINSKI, M. Justifying capital expenditures in new technology: A survey. Engineering Economist. 1999, Vol. 44, Iss. 4, pp. 362-376. ISSN 0013-791X. DOI:10.1080/00137919908967529.

[8] COULTHURST, N.J. Accounting for inflation in capital investment: the state of the art and science. Accounting and Business Research. 1986, Vol. 17, Iss. 65, pp. 33-42. ISSN 0001-4788. [9] DEAN, J. Measuring the productivity of capital. Harvard Business Review. 1954, Vol. 32, Iss. 1, pp. 120-130. ISSN 0017-8012.

[10] DRURY, C., BRAUND, S., OSBORNE, P., TAYLES, M. A Survey of Management Accounting Practices in UK Manufacturing Companies. London: Chartered Association of Certified Accountants. 1993. ISBN 0900094915. [11] FISHER, E.L., NOF, S. Knowledge-based economic analysis of manufacturing systems. Journal of Manufacturing Systems. 1987, Vol. 6, Iss. 2, pp. 137-150. ISSN 1878-6642.

[12] FOTR, J., PLEVNÝ, M., ŠVECOVÁ, L., VACÍK, E. Multi-criteria Project Portfolio Optimization under Risk and Specific Limitation. E+M Ekonomie a Management. 2013, Vol. 16, Iss. 4, pp. 71-88. ISSN 1212-3609.

[13] FRANKFORT-NACHMIAS, C., NACHMIAS, D. Research Methods in the Social Sciences. 5th ed. London: Arnold, 1996. ISBN 0340662263.

[14] GALLO, P., PECCATI, L. The appraisal of industrial investments: A new method and a case study. International Journal of Production
Economics. 1993, Vol. 30-31, Iss. July, pp. 465476. ISSN 0925-5273. DOI:10.1016/09255273(93)90113-Y.

[15] GLAUTIER, M.W.E., UNDERWOOD, B. Accounting Theory and Practice. London: Pitman Publishing, 1991. ISBN 0-273-03311-5. [16] GREGORY, A., RUTTERFORD, J., ZAMAN, $M$. The Cost of Capital in the UK: A Comparison of the Perceptions of Industry and the City. London: CIMA, 1999. ISBN 1859713351.

[17] GUNASEKARAN, A., LOVE, P.E.D., RAHIMI, F., MIELE, R. A model for investment justification in information technology projects. International Journal of Information Management. 2001, Vol. 21, No. 5, pp. 349364. ISSN 1873-4707. DOI:10.1016/S02684012(01)00024-X.

[18] HÁJEK, L., HYNEK, J., JANEČEK, V., LEFLEY, F., WHARTON, F. Investment appraisal of advanced manufacturing technology in the Czech Republic, USA and United Kingdom. Prague Economic Papers. 2001, Vol. 10, Iss. 2, pp. 174-188. ISSN 1210-0455.

[19] HARRIS, E.P., EMMANUEL, C.R., $\mathrm{KOMAKECH}$, S. Managerial Judgement and Strategic Investment Decisions - A CrossSectional Survey. Oxford: CIMA/Elsevier, 2009. ISBN 18561782310.

[20] HENDRICKS, J.A. Capital Budgeting Decisions: NPV or IRR? Cost and Management. 1980, Iss. March/April, pp. 16-20. ISSN 00109592.

[21] ICMA. The Profitable Use of Capital in Industry. London: ICMA, 1965.

[22] KEE, R., BUBLITZ, B. The role of payback in the investment process. Accounting and Business Research. 1988, Vol. 18, Iss. 70, pp. 149-155. ISSN 0001-4788.

[23] KELLY, G., TIPPETT, M. Economic and accounting rates of return: a statistical model. Accounting and Business Research. 1991, Vol. 21, Iss. 84, pp. 321-329. ISSN 0001-4788.

[24] LEFLEY, F. The payback method of investment appraisal: A review and synthesis. International Journal of Production Economics. 1996, Vol. 44, Iss. 3, pp. 207-224. ISSN 0925-5273. [25] LEFLEY, F. The sometimes overlooked discounted payback method. Management Accounting. 1997, Vol. 75, Iss. 10, pp. 36. ISSN 0025-1690.

[26] LEFLEY, F. A new dimension: calculating the modified internal rate of return from the net present value. International Accountant. 200505-27, pp. 24-25. ISSN 1465-5144. 
[27] LEFLEY, F., SARKIS, J. The decline of the accounting rate of return (ARR). Management Accounting. 1997, Vol. 75, Iss. 6, pp. 50-52. ISSN 0025-1690.

[28] LEVY, H., SARNAT, M. Capital Investment \& Financial Decisions. 5th ed. New York: Prentice Hall, 1994. ISBN 978-0-131-15882-5.

[29] LIN, S.A.Y. The modified internal rate of return and investment criterion. Engineering Economist. 1976, Vol. 21, Iss. 4, pp. 237-247. ISSN 0013-791X.

[30] LOHMANN, J.R., BAKSH, S.N. The IRR, NPV and payback period and their relative performance in common capital budgeting decision procedures for dealing with risk. Engineering Economist. 1993, Vol. 39, Iss. 1, pp. 17-47. ISSN 0013-791X.

[31] LUMBY, S. Investment Appraisal and Financial Decisions. London: Chapman and Hall, 1994. ISBN 1861522576.

[32] MAO, J.C.T. The internal rate of return as a ranking criteria. Engineering Economist. 1966, Vol. 11, Iss. 4, pp. 1-13. ISSN 0013-791X. [33] MERRETT, A.J., SYKES, A. Capital Budgeting and Company Finance. 2nd ed. London: Longman, 1973. ISBN 0582450586.

[34] NARAYANAN, M.P. Observability and the payback criterion. Journal of Business. 1985, Vol. 58, Iss. 3, pp. 309-323. ISSN 0021-9398.

[35] PEARSON, G. The strategic discount protecting new business projects against DCF. Long Range Planning. 1986, Vol. 19, Iss. 1, pp. 18-24. ISSN 0024-6301.

[36] PIKE, R.H. Disenchantment with DCF promotes IRR. Certified Accountant. 1985, Iss. July, pp.14-17. ISSN 0306-2406.

[37] PIKE, R.H. An empirical study of the adoption of sophisticated capital budgeting practices and decision-making effectiveness. Accounting and Business Research. 1988, Vol. 18, Iss. 72, pp. 341-351. ISSN 0001-4788.

[38] RAPPAPORT, A. The discounted payback period. Management Services. 1965, Iss. July/ August, pp. 30-36. ISSN 0025-1917.

[39] REUL, R.I. Profitability index for investments. Harvard Business Review. 1957, Vol. 35, Iss. 4, pp. 116-132. ISSN 0017-8012.

[40] ROBBICHEK, A.A., MYERS, S.C. Conceptual problems in the use of risk-adjusted discount rates. Journal of Finance. 1966, Vol.
21, Iss. 4, pp. 727-730. ISSN 1540-6261.

[41] SAMUELS, J.M., WILKES, F.M., BRAYSHAW, R.E. Management of Company Finance. 5th ed. London: Chapman and Hall, 1990. ISBN 0412374706.

[42] SANDAHL, C., SJÖGREN, S. Capital budgeting methods among Sweden's largest groups of companies. The state of the art and a comparison with earlier studies. International Journal of Production Economics. 2003, Vol. 84, Iss. 1, pp. 51-69. ISSN 0925-5273. DOI:10.1016/ S0925-5273(02)00379-1.

[43] SICK, G.A. A certainty-equivalent approach to capital budgeting. Financial Management. 1986, Vol. 15, Iss. 4, pp. 23-32. ISSN 1755-053X.

[44] SOLOMON, E. The arithmetic of capitalbudgeting decisions. Journal of Business. 1956, Vol. 29, Iss. 2, pp. 124-129. ISSN 0021-9398.

[45] SUNDEM, G.L. Evaluating simplified capital budgeting models using a time-state preference matric. Accounting Review. 1974, Vol. 49, Iss. 2, pp. 306-320. ISSN 0001-4826.

[46] WARD, J., TAYLOR, P., BOND, P. Evaluation and realisation of IS/IT benefits: an empirical study of current practices. European Journal of Information Systems. 1996, Vol. 4, Iss. 4, pp. 214-225. ISSN 0960-085X. DOI:10.1057/ ejis.1996.3.

prof. RNDr. Josef Hynek, Ph.D., MBA

University of Hradec Králové

Faculty of Informatics and Management Department of Informatics and Quantitative Methods josef.hynek@uhk.cz

doc. Ing. Václav Janeček, CSc.

University of Hradec Králové

Faculty of Informatics and Management Department of Economics vaclav.janecek@uhk.cz

Dr Frank Lefley PhD, Mphil, MSc University of Hradec Králové

Faculty of Informatics and Management Department of Economics frank.lefley@uhk.cz 


\title{
Abstract
}

\section{AN EXPLORATORY STUDY OF A COMPARISON BETWEEN THE UK AND CZECH REPUBLIC OF THE FINANCIAL MODELS USED IN THE APPRAISAL OF ICT AND NON-ICT CAPITAL PROJECTS}

\author{
Josef Hynek, Václav Janeček, Frank Lefley
}

Our research is aimed at identifying the current practices in respect of the financial appraisal of information communication technology and non-ICT projects. We look specifically at the UK a well-established market economy - and the Czech Republic - an emerging market economy. Our research is based on a unique survey, which simultaneously examines the financial appraisal models used in the two types of projects, and addresses these issues from two diverse market economies. An important finding is that any differences in the financial models used relate to the two countries rather than between ICT or non-ICT projects. While both countries make extensive use of the payback model, they fully defend the view that this model influences a short-term mentality. The Czech Republic, more so than the UK, also support the view that the payback is unsuitable for appraising information communication technology projects, yet they still use it to appraise such projects. The Czech Republic places less importance on the discounted cashflow models than the UK, with the Czech Republic preferring the 'net present value' to the 'internal rate of return'. The UK, by using an 'opportunity cost of capital' approach in the determination of the 'discount rate', may be making it harder to achieve a positive net present value than the Czech Republic, who adopt an approach which is nearer to the true cost of capital. This exploratory study will aid both practitioners and academics in a greater understanding of the appraisal of capital assets and focus future research in a positive way.

Key Words: Investment appraisal, information communication technology, ICT, emerging markets, DCF.

JEL Classification: D22, D24, D81.

DOI: 10.15240/tul/001/2015-2-007 